\title{
Isolation and identification of Legionella pneumophila from drinking water in Basra governorate, Iraq
}

A.A. Al-Sulami, ${ }^{1}$ A.M.R. Al-Taee ${ }^{2}$ and A.A. Yehyazarian ${ }^{2}$

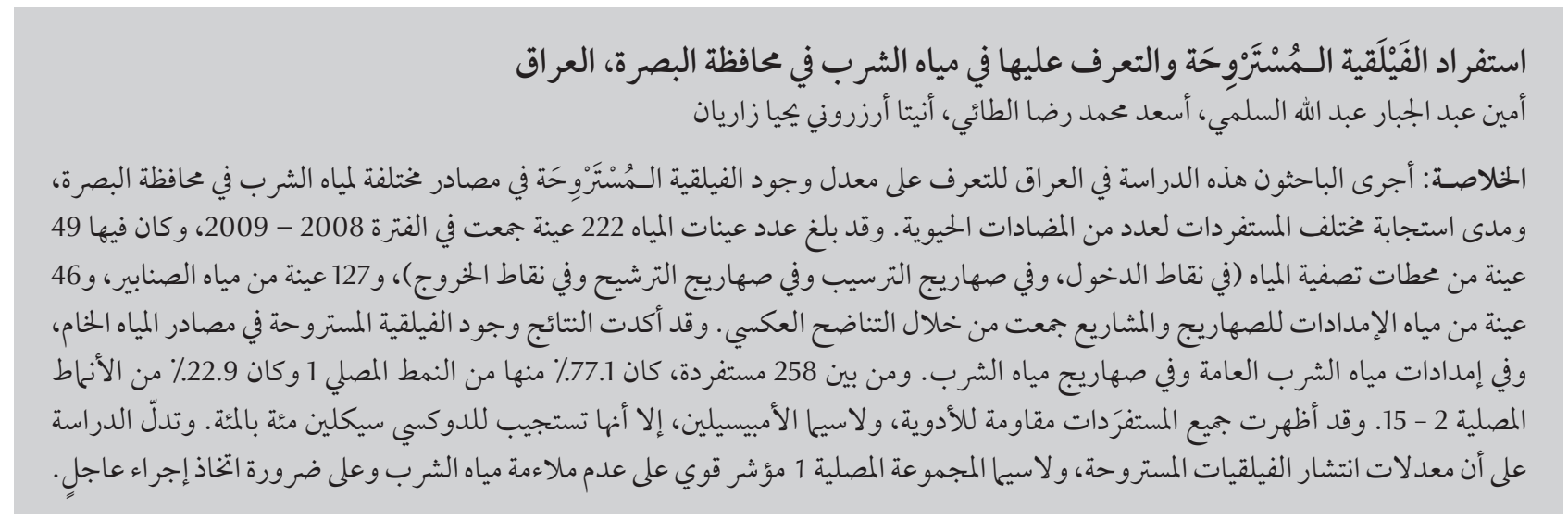

ABSTRACT This study in Iraq investigated the occurrence of Legionella. pneumophila in different drinkingwater sources in Basra governorate as well as the susceptibility of isolates to several antibiotics. A total of 222 water samples were collected in 2008-2009: 49 samples from water purification plants (at entry points, from precipitation tanks, from filtration tanks and at exit points), 127 samples of tap water; and 46 samples from tankers and plants supplying water by reverse osmosis. The findings confirmed the presence of $L$. pneumophila in sources of crude water, in general drinking water supplies and drinking water tankers. Of 258 isolates $77.1 \%$ were serotype 1 and $22.9 \%$ serotypes $2-15$. All examined isolates displayed drug resistance, particularly to ampicillin, but were $100 \%$ susceptible to doxycycline. The prevalence of $L$. pneumophila, especially serogroup 1 , is a strong indicator of unsuitability of drinking water and requires appropriate action.

Isolement et identification de Legionella pneumophila dans l'eau potable dans le gouvernorat de Bassora (Iraq)

RÉSUMÉ Une étude en Iraq visait à évaluer l'occurrence de Legionella pneumophila dans différentes sources d'eau potable dans le gouvernorat de Bassora ainsi que la sensibilité des isolats à plusieurs antibiotiques. Au total, 222 échantillons d'eau ont été prélevés en 2008 et 2009 : 49 échantillons de stations d'épuration des eaux usées (aux points d'entrée, dans les cuves de précipitation, dans les cuves de filtration et aux points de sortie), 127 échantillons d'eau du robinet et 46 échantillons d'eau de camions-citernes et d'établissements fournissant de l'eau par osmose inverse. Les résultats ont confirmé la présence de $L$. pneumophila dans les sources d'eau brute, dans les sources d'approvisionnement générales et les camions-citernes d'eau de boisson. Sur 258 isolats, $77,1 \%$ étaient de sérotype 1 et 22,9\% de sérotypes $2-15$. Tous les isolats examinés étaient pharmacorésistants, en particulier à l'ampicilline, mais $100 \%$ étaient sensibles à la doxycycline. La prévalence de L. pneumophila, notamment du sérogroupe 1, est un puissant indicateur du caractère impropre à la consommation de l'eau de boisson et appelle des mesures adéquates.

'Department of Biology, College of Education, University of Basra, Basra, Iraq (Correspondence to A.A. Al-Sulami: Aminabdulah@yahoo.com). ${ }^{2}$ Department of Marine Environmental Chemistry, Marine Science Centre, Basra, Iraq.

Received: 06/04/12; accepted: 30/07/12 


\section{Introduction}

The Legionella pneumophila species of bacteria comprises over 15 serogroups [1], of which serogroup 1 is responsible for the majority of human infections [2]. Two clinical manifestations have been defined within this spectrum: Legionnaires' disease, which is a pneumonic illness caused by an acute bacterial infection of the lower respiratory tract; and Pontiac fever, which is an influenzalike illness [3]. This Gram-negative bacterium survives in water systems as a parasite of protozoa [4], which are readily found in cooling towers, hotwater distribution systems, bathrooms, swimming pools and fountains $[5,6]$. Infection results when L. pneumophila are transmitted from an environmental source (water or soil) to a host via the inhalation of contaminated aerosols. However, there have been no reports of human-to-human transmission [1]. Therefore, studies concerning the presence of these organisms in drinkingwater distribution systems are very important to ensure the good quality of public water.

The present study in Iraq aimed to investigate the occurrence of L. pneumophila in different drinking-water sources in Basra governorate (water sanitation plants, drinking water from different districts and reverse-osmosis water-supply plants), as well as the susceptibility of isolates to several antibiotics.

\section{Method}

\section{Water samples}

A total of 222 water samples were collected in Basra governorate during the period from August 2008 to April 2009. These included: 49 samples from all 13 water purification plants in the governorate (13 samples from entry points, 13 from precipitation tanks, 10 from filtration tanks and 13 samples from exit points); 127 samples of tap water collected from 18 districts; and 46 water samples collected from reverse-osmosis water suppliers (from tankers supplying water by reverse osmosis in 19 different places and from 5 water-supply plants).

The samples were collected according to Standard methods for examination of water and wastewater [7] into sterile sampling bottles, with $10 \mathrm{~mL}$ of a sodium thiosulphate solution at $1 \%$ in order to neutralize any residual chlorine. The water samples were directly placed in ice, for transportation and examination within the same day. The concentration of residual chlorine for each sample was measured using a chlorine meter (Lovibond 2000) at the time of collection.

\section{Isolation}

A duplicate of $5 \mathrm{~mL}$ of each sample from water purification plants and tap water and $100 \mathrm{~mL}$ of water samples from reverse-osmosis plants and tankers was filtered by the membrane filtration technique using $47 \mathrm{~mm}$ cellulose acetate membrane filters with a nominal pore size of $0.45 \mu \mathrm{m}$ (Sartorius). The membrane filter papers were placed on $\mathrm{m}-\mathrm{FC}$ agar and incubated in a water bath at $44.5^{\circ} \mathrm{C}$ for $24 \mathrm{~h}$ and on Legionella agar base (LAB) medium [8] containing Legionella growth supplement and Legionella-selective supplement which contained dyes, colistin sulphate, vancomycin, trimethoprim and amphotericin B (Himedia). They were incubated at $35^{\circ} \mathrm{C}$ in an incubator with humidified atmosphere for 24-72 $\mathrm{h}$.

\section{Identification}

Suspected colonies were subcultured in parallel onto LAB medium and were subjected to Gram stain, oxidase, catalase, nitrate reduction, motility, gelatin liquefaction, urease and hippurate test. In addition the slide-agglutination test [1] (HiLegionella latex kit, HiMedia) was used for confirmatory identification of L. pneumophila to serogroup 1 and serogroups 2-15.

\section{Antimicrobial susceptibility testing}

Isolates were tested for antimicrobial susceptibility by the Stoke disk diffusion method [9] using Mueller-Hinton agar and antibiotic disks (Bioanalyse). The following disks were used: doxycycline $(30 \mu \mathrm{g})$, erythromycin $(15 \mu \mathrm{g})$, streptomycin $(10 \mu \mathrm{g})$, gentamicin $(10 \mu \mathrm{g})$, chloramphenicol $(30 \mu \mathrm{g})$ and ampicil$\operatorname{lin}(10 \mu \mathrm{g})$. The plates were incubated at $37^{\circ} \mathrm{C}$ overnight. The diameter of zone of inhibition of each antimicrobial agent was measured and recorded as resistant, sensitive or intermediate according to the manufacturer's table.

\section{Results}

\section{Purification plant samples}

The logarithmic numbers of L. pneumophila and faecal coliforms from the 13 water purification plants in Basra governorate are shown in Figure 1. All stations (except 1) showed the presence of both L. pneumophila and faecal coliforms in raw water. There was no obvious reduction of these 2 groups in precipitation and filtration tanks. Few stations, $(5 / 13)$ showed the presence of L. pneumophila, whereas $9 / 13$ were positive for faecal coliforms in water coming from treatment plants. In precipitation tanks 3/13 stations showed higher number of L. Pneumophila, while in the filtration tanks 2/13 stations showed higher numbers of L. pneumophila.

Of the 106 isolates recovered from purification plant samples on LAB medium, 55 of them belonged to $L$. pneumophila serogroup 1 while the rest belonged to L. pneumophila serogroups 2-15.

\section{Tap water samples}

Table 1 shows the average of the logarithmic numbers of L. pneumophila and faecal coliforms and the concentration of residual chlorine for the 127 samples of drinking tap water collected from 18 districts. 


\begin{tabular}{|c|c|c|c|c|c|}
\hline District & $\begin{array}{l}\text { No. of } \\
\text { samples }\end{array}$ & $\begin{array}{c}\text { Average of } \\
\text { residual chlorine } \\
\text { concentration }(\mathrm{mg} / \mathrm{L})\end{array}$ & $\begin{array}{l}\text { Average log no. of } \\
\text { fecal coliforms }\end{array}$ & $\begin{array}{l}\text { Average of log no. of } \\
\text { L. pneumophila }\end{array}$ & $\begin{array}{l}\text { No. of } L . \text { pneumophila } \\
\text { isolates }\end{array}$ \\
\hline Old Basra & 9 & 1.03 & 2.89 & 1.66 & 10 \\
\hline Al-Jame'eyat & 3 & 0.05 & 3.03 & 1.84 & 5 \\
\hline Al-Ashar & 17 & 0.04 & 3.44 & 1.72 & 18 \\
\hline Al-Ma'aqal & 13 & 0.17 & 3.43 & 1.71 & 15 \\
\hline Al-Hakeemya & 8 & 0.63 & 2.91 & 1.50 & 5 \\
\hline Shatt-Al-Arab & 10 & 0.44 & 2.66 & 2.14 & 8 \\
\hline Al-Esmae'e & 5 & 0 & 2.32 & 1.30 & 4 \\
\hline Al-Hussain & 8 & 1.01 & 2.78 & 1.81 & 8 \\
\hline Al-Tuwaisa & 6 & 0 & 3.18 & 2.61 & 8 \\
\hline Al-Hadi & 4 & 0 & 3.60 & 1.44 & 6 \\
\hline Al-Abela & 3 & 0 & 3.44 & 1.54 & 7 \\
\hline Al-Jubaila & 5 & 1.4 & 4.00 & 1.54 & 7 \\
\hline Al-Jazae'er & 3 & 0 & 2.87 & 1.30 & 5 \\
\hline Al-Jumhurya & 3 & 0 & 2.33 & 89.1 & 3 \\
\hline Al-Junaina & 5 & 0.02 & 3.72 & 1.57 & 5 \\
\hline Al-Mowafakai & 5 & 0 & 2.66 & 87.1 & 5 \\
\hline Al-Fayhaa & 9 & 0.31 & 2.32 & 2.31 & 8 \\
\hline Abu-Al-Khaseeb & 11 & 1.32 & 2.34 & 1.60 & 12 \\
\hline Total & 127 & - & - & - & 139 \\
\hline
\end{tabular}

A total of 133 isolates of L. pneumophila serogroup 1 were isolated from these districts, while only 6 isolates of serogroups 2-15 were isolated from Al-Jubaila and Al-Junaina districts. All stations were positive for L. pneumophila at frequencies much higher than those recorded for the water coming from treatment plants.

\section{Reverse-osmosis water samples}

A total of 41 samples were collected from reverse-osmosis water-supply tankers in 19 different districts in Basra governorate. The average of logarithmic numbers of L. pneumophila and faecal coliforms indicated the presence of $L$. pneumophila in 6/19 stations while faecal coliforms was recorded in $12 / 19$ stations. Only 8 isolates of L. pneumophila serogroup 1 were isolated from reverseosmosis water tankers.

In addition 5 main reverse-osmosis plants in Basra governorate were tested for L. pneumophila, indicating the presence of L. pneumophila in only $1 / 5$ stations as compared to $3 / 5$ stations harbouring faecal coliforms. Only 3 isolates of L. pneumophila serogroup 1 were isolated from the reverse-osmosis plants of the General Company of Petrochemical Industries.

\section{Serogroups}

The total number of L. pneumophila isolated on LAB medium were 258; serogroup 1 (199 isolates) comprised $77.1 \%$ of total isolates and serogroups 2-15 (59 isolates), comprised $22.9 \%$ of total isolates.

\section{Antibiotic susceptibility tests}

Antibiotic susceptibility testing was done for 10 L. pneumophila isolates, 8 isolates belonging to serogroup 1 , and 2 isolates belonging to serogroups $2-15$. Among serogroup 1 isolates there was $83.0 \%$ resistance to ampicillin, $37.5 \%$ to erythromycin and $50.0 \%$ to chloramphenicol and gentamicin, but $100 \%$ sensitivity to doxycycline. On other hand, isolates of serogroups $2-15$ showed $75.0 \%$ resistance to ampicillin, $100 \%$ intermediate sensitive to erythromycin and streptomycin, 50\% sensitive to chloramphenicol and gentamicin and $100 \%$ sensitive to doxycycline.

\section{Discussion}

Water is a fundamental need for all forms of life, yet human beings continue to pollute the reserves which still remain, thus increasing the risk of diseases that can jeopardize the population [10]. In this study using LAB medium as a selective medium for isolating $L$. pneumophila, most of the water samples in Basra governorate were found to be positive for growth of L. pneumophila. These bacteria were isolated from raw water entering the plants and their numbers were uncountable in some plants, confirming that water is a natural reservoir for Legionella spp. The bacterium is ubiquitous in fresh water 


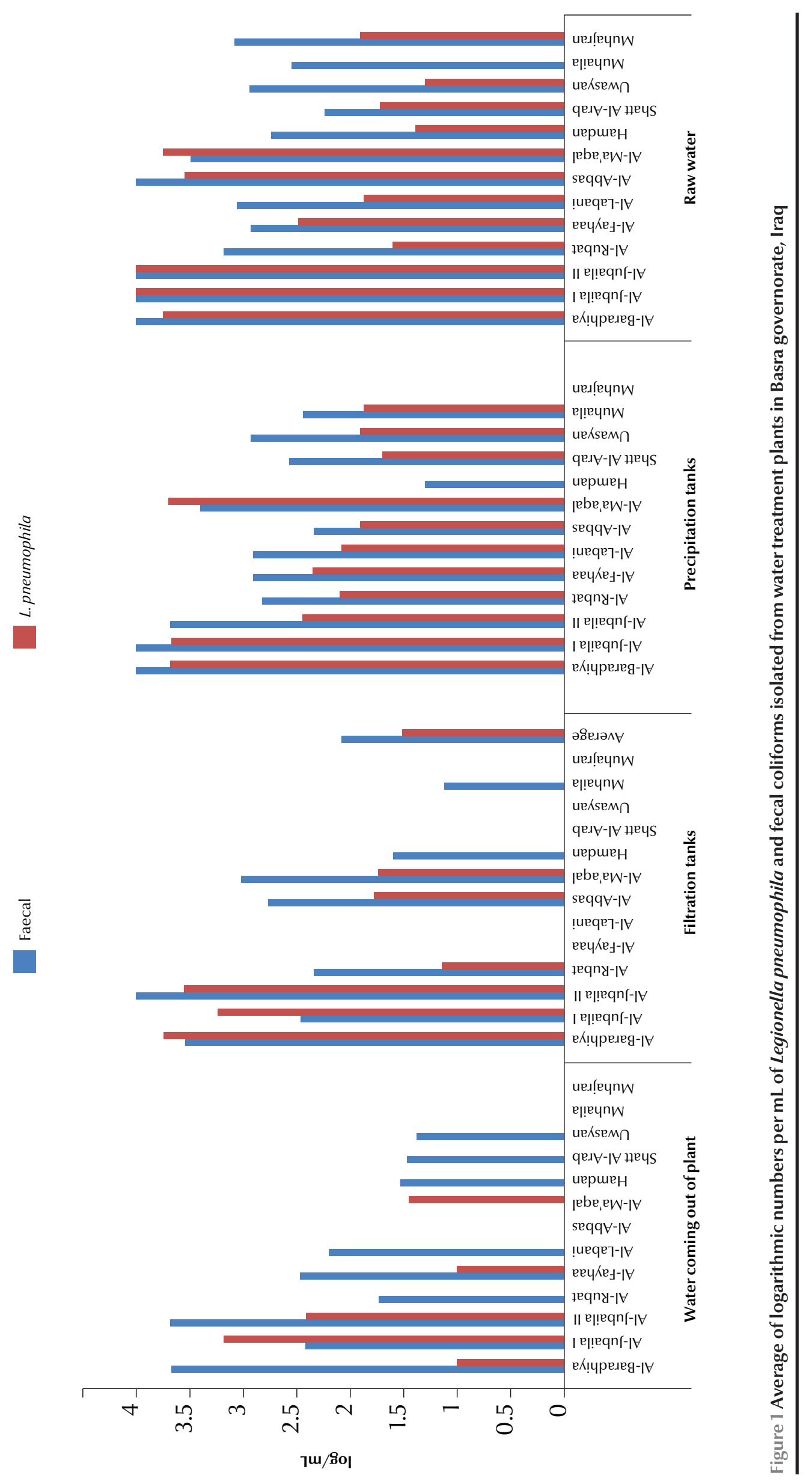


sources [11], which may be due to the inadequacy of sewage water processing before it is dumped into rivers. This bacterium is also able to infect protozoa, a relationship that provides protection for the bacterium against adverse environmental conditions [12], in addition to the presence of organic materials that provide nutrients for Legionella spp. growth. This study was similar to that of Wullings and van der Kooij who used culture methods and polymerase chain reaction techniques [13].

L. pneumophila were also isolated from precipitation tanks and it was noted that in some plants the numbers were higher than the numbers in raw water. This may be a result of inefficiency in the primary treating stage of the raw water entering the plants, suggesting that the precipitation tanks work as a reservoir for the growth of these bacteria, perhaps due to the presence of suitable conditions such as precipitants and growth of algae.

L. pneumophila were also present in the filtration units in some of the purification plant samples in Basra and this could be ascribed to the fact that some of the plants are old and/or the filters used in these units are old and there is no maintenance or periodic cleaning or changing of filters. It was observed that in other water treatment plants these bacterium were not detected which provides evidence for the efficiency of filtration units in some cases, which is in agreement with the findings of Bomo et al. [14]. The high growth in the filtration stage of water treatment plants is known to occur in areas of slow-moving water, which may allow growth-supporting materials to accumulate. Passage of water through the rapid sand-filters of the plant almost completely reduces the potential for growth of bacteria, due to removal of growth-enhancing factors and reducing the residence time of bacteria; these findings are similar to the observations of Hoekstra et al. on water passing through rapid and slow sand filters [15].
For the samples of water emerging from plants, it was noted that $L$. pneumophila was absent in most plants and the number of isolates varied between plants, which may be due to the differences in remaining chlorine concentrations in the emission water, as chlorine activity depends on factors such as temperature and $\mathrm{pH}[2]$; these results are compatible with $\mathrm{Hsu}$ et al. [16]. L. pneumophila is more resistant than other organisms to common standard disinfecting methods. It may, therefore, be found even in disinfected waters with residual chlorine content [17]. A decrease in, or even absence of, chlorine at the extreme ends of the water distribution system increases the risk of growth of the bacterium.

L. pneumophila was isolated from drinking (tap) water in different percentages from district to district and in different areas in the same district of the governorate. The difference in the numbers of isolates across different districts may be due to differences in the biological membranes (biofilms) formed in the distribution pipe networks [18]. Biofilms are essential for growth and proliferation of this bacterium [19]. The combination of organic elements, inorganic elements and the right water temperature create a good environment for L. pneumophila proliferation $[20,21]$. Several studies have indicated that the type of materials of water supply systems (rubber, stainless steel or polyvinyl chloride) affects the formation biofilms [22]. It is well known that Iraq suffers from chronic water deficiency and therefore water treatment plants may not operate in a continuous manner. This creates conditions that contribute to the deterioration of water quality, mainly due to the precipitation and regrowth of pollutants in network pipes, as most of the networks undergo continuous breakage and corrosion that facilitates the entry of pollutants from rain water or infiltration of sewage water into networks. These results are similar to data reported in the literature, in which L. pneumophila was the predominant species in freshwater and municipal drinking water supplies [23] and L. pneumophila serogroup 1 was isolated at high frequencies in buildings [24].

Regarding samples of water treated by reverse osmosis it was found that 20 samples were positive for L. pneumophila, which is compatible with what Goutziana et al. have observed [25]. Sunlight, temperature, $\mathrm{pH}$ and biofilms are factors that affect bacterial activity [13]. This is in addition to the risk of pollution of water during transportation and storage, due to inadequate cleaning and drying practices which provide suitable conditions for the growth and reproduction of pollutants in the stored water.

No association was observed between L. pneumophila and the presence of faecal coliforms in our study as $L$. pneumophila were detected in water samples in the absence of faecal coliforms. This opportunistic pathogen has commonly been isolated in the absence of faecal contamination [26].

Development of resistance to antibiotics may be due to increasing use of antibiotics for medical and agricultural purposes and there has been a rise in resistance to these drugs [27]. In the present study isolates were more resistant to ampicillin and less resistant to erythromycin, chloramphenicol and gentamicin. Resistance to ampicillin has been reported previously among Legionella spp., due to beta-lactamase production [28]. Erythromycin has usually been considered the antibiotic of choice for the treatment of Legionnaires' disease, but newer antibiotics that are more potent and less toxic are now replacing it [29]. For aminoglycosides such as gentamicin, the mechanism of resistance that is predominantly observed clinically is chemical alteration of the drug catalysed by aminoglycoside-modifying enzymes [30,31]. In this study as all examined isolates were sensitive to 
doxycycline, confirming the efficacy of doxycycline on L. pneumophila isolates as demonstrated in 7 European countries [32].

This is the first report of L. pneumophila in water samples including water sanitation plants, reverse-osmosis water supplies and samples of tap water from different districts of Basra city, Iraq. The findings confirmed the presence of L. pneumophila in crude water sources and in general drinking water supplies and tankers of drinking water. The prevalence of L. pneumophila, especially serogroup 1 , is a strong indicator of unsuitability of drinking water and requires appropriate action.

Competing interests: None declared.

\section{References}

1. Forbes BA, Sahm DF, Weissfeld AS. Bailey and Scott's diagnostic microbiology, 12th ed. St Louis, Missouri, Mosby, 2007.

2. De Jong MD, Hien TT. Avian influenza A (H5N1). Journal of Clinical Virology, 2006, 35:2-13.

3. Hoge CW, Breiman RF. Advances in the epidemiology and control of Legionella infections. Epidemiologic Reviews, 1991, 13:329-340.

4. Fields BS. The molecular ecology of legionellae. Trends in Microbiology, 1996, 4:286-290.

5. Abrail D, Riffard S. Detection and identification of Legionella species from ground waters. International Journal of Hygiene and Environmental Health, 2004, 67(Part A):1845-1849.

6. Sabria M et al. A community outbreak of Legionnaires' disease: evidence of a cooling tower as the source. Clinical Microbiology and Infection, 2006, 12:642-647.

7. Standard methods for the examination of water and wastewater, 20th ed. Washington DC, American Public Health Association/American Water Works Association/ Water Environment Federation, 1995.

8. Water quality-detection and enumeration of Legionella. ISO 11737:1998. Geneva, International Organization for Standardization, 1998.

9. Stokes EJ. Ridgway Gl, eds. Clinical bacteriology, 5th ed. London, Arnold, 1980:215.

10. Companhia de Saneamento Básico do Estado de São Paulo S.A (Sabesp) [website] [http://www.sabesp.com.br/, accessed 14 July 2013) [in Portugese].

11. Riffard S et al. Occurrence of Legionella in groundwater: an ecological study. Water Science and Technology, 2001, 43:99-102.

12. Decludt B et al. Clusters of travel associated Legionnaires' disease in France, September 2001-August 2003. Euro Surveillance, 2004, 9:11-13.

13. Wullings BA, van der Kooij D. Occurrence and genetic diversity of uncultured Legionella spp. in drinking water treated at temperatures below 15 degrees C. Applied and Environmental Microbiology, 2006, 72:157-166.

14. Bomo AM et al. Bacterial removal and protozoan grazing in biological sand filters. Journal of Environmental Quality, 2004, 33:1041-1047.

15. Hoekstra AC, van der Kool D, Unen WAMH. Bacteriological, chemical, and physical characteristics of samples from two hot water systems containing Legionella pneumophila compared with drinking water from municipal water works. In: Thornsberry C, et al. eds. Legionella. Proceedings of the 2nd International Symposium. Washington DC, American Society for Microbiology, 1984:343-346.

16. Hsu SC, Martin R, Wentworth BB. Isolation of Legionella species from drinking water. Applied and Environmental Microbiology, 1984, 48:830-832.

17. Legionella drinking water health advisory. Washington DC, United States Environmental Protection Agency, Office of Water, 2001.
18. Momba MNB, Makala N. Comparing the effect of various pipe materials on biofilm formation in chlorinated and combined chlorine-chlorinated water systems. Water SA, 2004, 30(2):175-182.

19. Lin YS et al. Disinfection of water distribution systems for Legionella. Seminars in Respiratory Infections, 1998a, 13:147-159.

20. Prevost M, Laurent P, Servais P. Biodegradable organic matter in drinking water treatment and distribution. Denver, Colorado, American Water Works Association, 2005.

21. Al-Wazzan $\mathrm{Y}$ et al. Desalting of subsurface water using spiralwound reverse osmosis (RO) system: technical and economic assessment. Desalination, 2002, 143:21-28.

22. Kuiper MW et al. Intracellular proliferation of Legionella pneumophila in Hartmannella vermiformis in aquatic biofilms grown on plasticized polyvinyl chloride. Applied and Environmental Microbiology, 2004, 70:6826-6833.

23. Gião MS et al. Incorporation of natural uncultivable Legionella pneumophila into potable water biofilms provides a protective niche against chlorination stress. Biofouling, 2009, 25:345-351.

24. Pelaz C, Martín C. Legionella infection in Spain: analysis of human and environmental strains isolated between 1980 and 1999. [Infección por Legionella en España: análisis de las cepas humanas y ambientales aisladas entre 1980 y 1999.] Enfermedades Emergentes, 2000, 2:214-219

25. Goutziana $\mathrm{G}$ et al. Legionella species colonization of water distribution systems, pools and air conditioning systems in cruise ships and ferries. BMC Public Health, 2008, 8:390.

26. Lehtola MJ et al. Survival of Mycobacterium avium, Legionella pneumophila, Escherichia coli, and caliciviruses in drinking water-associated biofilms grown under high-shear turbulent flow. Applied and Environmental Microbiology, 2007, 73:2854-2859.

27. Čižman M. The use and resistance to antibiotics in the community. International Journal of Antimicrobial Agents, 2003, 21:297-307.

28. Fung-Tomc JC et al. Activity of carbapenem BMS-181139 against Pseudomonas aeruginosa is not dependent on porin protein D2. Antimicrobial Agents and Chemotherapy, 1995, 39:386-393.

29. Baltch AL et al. Antibacterial activities of gemifloxacin, levofloxacin, gatifloxacin, moxifloxacin and erythromycin against intracellular Legionella pneumophila and Legionella micdadei in human monocytes. Journal of Antimicrobial Chemotherapy, 2005, 56:104-109.

30. Wright GD. Mechanisms of resistance to antibiotics. Current Opinion in Chemical Biology, 2003, 7:563-569.

31. Wybenga-Groot LE et al. Crystal structure of an aminoglycoside 6'-N-acetyltransferase: defining the GCN5-related Nacetyltransferase superfamily fold. Structure, 1999, 7:497-507.

32. Critchley IA et al. In vitro activity of levofloxacin against contemporary clinical isolates of Legionella pneumophila, Mycoplasma pneumoniae and Chlamydia pneumoniae from North America and Europe. Clinical Microbiology and Infection, 2002, 8:214-221. 